\title{
Institutional Support of Public Procurement Logistics: International and Domestic Experience
}

\author{
Borisova V.V. \\ Saint Petersburg University of Economics, \\ Saint-Petersburg, Russia, \\ verabrsv@yandex.ru
}

\author{
Pechenko N.S \\ Saint Petersburg University of Economics, \\ Saint-Petersburg, Russia, \\ natalya-oteva@yandex.ru
}

\author{
Xuedong $\mathrm{J}$. \\ Saint Petersburg University of Economics, \\ Saint-Petersburg, Russia, \\ 649051566@qq.com
}

\begin{abstract}
Institutional support of public procurement logistics is presented in the context of innovative transformations based on the results of monitoring procurement processes in international and Russian practice. Based on the comparison of existing models of public procurement in the world practice, the stability of representations to the understanding of logistics institutions in the procurement is shown. Attention is paid to the elements of the logistics system of public procurement, the emergence of new institutions caused by digital transformations of procurement processes. It is noted that a feature of modern public procurement systems is close interaction with logistics companies. New organizational forms of logistics flows are a set of digital communication platforms. This is a special type of public-private partnership that operates primarily in the interests of the state. Against the background of digitalization of commerce and development of e-commerce, there is a problem of increasing the competitiveness of public procurement. It is possible to implement, using the logistics toolkit, adapting the principles and methods of procurement to digital transformations in the economy. Issues of digital transformation of institutional support for procurement procedures are becoming a priority in the logistics of public procurement. The problem of assessing the digital maturity of institutions that provide acceleration, mobility, flexibility and end-to-end management of the full cycle of public procurement has been identified. In some cases, new digital institutions replace traditional ones, or digital innovations rely on the old institutional framework. Identifying the features of institutional support for public procurement and searching for reserves for the use of logistics tools in the management of digital procurement systems determines the relevance of this study. There is a need for the creation and implementation of digital institutional transformations in procurement, while preserving the positive heritage of the previously well-established institutions. It is concluded that digital transformations in the world and Russian economic life make adjustments to the institutional support of public procurement. Digital technologies increase the requirements
\end{abstract}

for organizational, regulatory, social, transactional, resourcesaving, environmental, ethical and other institutions. The adaptation of digital institutions to the organization and planning of public procurement is an urgent and insufficiently studied problem.

Keywords-institutional environment, public procurement, digital logistics, procurement, digital technologies

\section{INTRODUCTION}

Issues of institutional support for public procurement logistics are relevant, since the level of development and digital maturity of institutions depends on the effectiveness of the procurement.

In the modern virtual-real world, logistics as an element of the region's institutional environment plays an integrating role in linking the economy elements. In terms of theory, we address the problem of digital transformation of the region's institutional logistics support.

For the region's economy, this problem is more related to the emergence of new markets for digital goods, services and products, the use of digital technologies and innovative business models that create value and increase revenue.

Speaking about the digital transformation of institutional logistics support for a particular region, it is advisable to study the existing set of institutions and consider different points of view on the essence of the changes taking place. We are beginning to understand logistics as an integral part of the region's institutional infrastructure [1]. This article is devoted to this issue.

\section{Methodology}

The methodology used in this study is based on a set of provisions of economic theory, the categorical apparatus of 
institutional theory, scientific provisions of logistics and international procurement, commerce and management tools. To solve the problem of institutional support of public procurement logistics, we turned to the "summing-up" of ideas from different sciences (interdisciplinary knowledge), which allow us to shed light on the solution of research tasks. In addition, we relied on regulatory documents and legislative acts that regulate the development of international and Russian procurements.

Research ideas about the essence of institutional support for public procurement logistics are formed on the basis of cumulative knowledge about the problem of procurement, studying the interaction of participants in the full procurement cycle, and evaluating the possibility of building a digital public procurement logistics system [2].

The combination of the above scientific provisions determined our position, as well as the theoretical and applied justification of the problem under study.

\section{DiscusSION OF THE PROBLEM}

Exploring the institutional support of public procurement logistics, let's turn to the concept of "institute" as an element of procurement. But first, we note that for us "a public institution as a set of norms and rules that determine the interaction of people in economic and social life" [3] is of priority importance, since it is public institutions that play a key role in maintaining a balanced and economically viable development of the system. The role of institutions in implementing digital transformation in the logistics system of public procurement is equally important.

In this context, the institute performs organizational, regulatory and administrative functions, interacting with subjects in the process of performing these functions. They can include both private and state organizations that implement certain economic functions [4].

The novelty of the logistics approach to public procurement is the combined integration of logistics with joint activities related to the public procurement process. Integration of logistics and public procurement will allow achieving, with minimal time and minimum financial costs, the purchase of high-quality products right on time, in a single system for managing material and informational flows [5]

Procurement logistics is based on procedures that allow finding suppliers of goods and services necessary for the enterprise. At the same time, important attention is paid to the search for suppliers to perform a variety of government functions, which is typical for public procurement needs. In addition to the main function (meeting the needs of a stateowned enterprise in goods and services), public procurement serves as a tool for state regulation of the economy, controlling the growth of prices for the necessary purchased goods and services [6]. An important feature of public procurement is that it is carried out on budget funds, which indicates the need for expediency and accountability of their use. The logistics system of public procurement is considered as "a set of operations for the procurement of resources for the performance of public functions with the maximum possible efficiency".

Foreign countries are characterized by the creation of national public procurement systems that allow them to solve the socio-economic problems of the state most effectively. This "set of practical methods and techniques used in the process of managing public procurement, in order to streamline procedures, facilitate them for participants, comply with the law, and prevent corruption" [7] is called procurement.

The combination of the concepts "institute" and "logistics of public procurement" makes it necessary to understand the terminological structure "logistics institutions in procurement".

In this case, we are dealing with the regulator of parameters and balanced development of the logistics system of public procurement.

To understand the specifics of the organization of public procurement, we will consider the basics of procurement for public needs in the Russian Federation and the People's Republic of China and conduct a comparative analysis.

In the Russian Federation, purchases for state needs are made on the basis of Federal law No. 44-FZ of 05.04.2013"On the contract system in the field of goods procurement, works, and services for state and municipal needs". The law on public procurement in the Russian Federation regulates the conditions for public procurement procedures, the procedure for concluding public contracts for the goods supply, performance of works or provision of services.

The parties involved in public procurement in the Russian Federation are state or municipal authorities, management bodies of extra-budgetary funds, budgetary or state-owned institutions, state or municipal unitary enterprises, State Atomic Energy Corporation "Rosatom" and Roscosmos State Space Corporation, and suppliers of goods/works/services.

The principles of the contract system in the Russian Federation, according to the law, include: openness and transparency; ensuring competition; professionalism of customers; unity of the contract system.

Public procurement planning in the Russian Federation is also regulated by Federal law 44-FZ. It is carried out on the basis of schedule plans that are developed and approved directly by each state customer before the start of the calendar year of procurement in accordance with the budget for the next financial year.

In the Russian Federation, the following methods of determining suppliers are used in public procurement:

- procurement from a single supplier;

- tenders (open tender, limited participation tender, twostage tender, closed tender, closed tender with limited participation, closed two-stage tender);

- bidding (electronic bidding, closed bidding);

- request for quotations;

- request for proposals.

Public procurement in electronic form is carried out on 8 specialized electronic trading platforms (the list of which is also fixed by law). The unified information system for posting information about ongoing public procurement in the Russian 
Federation is the Public Procurement Website https://zakupki.gov.ru.

In the People's Republic of China, public procurement is regulated by the law "On bidding and tendering" (TBL, 2000) and the law "On public procurement" (GPL, 2003).

The law on public procurement of the People's Republic of China establishes the conduct of public procurement "based on the principles of openness, transparency, fair competition, fairness, honesty and trust". Public procurement is the responsibility of the financial departments of the popular governments of China at all levels [8].

Public procurement is carried out at the expense of budget funds. The law pays great attention to the fact that public procurement must comply with both the general course of development of China and the goals of economic and social development of each individual region of China. used:

In China, the following types of tenders and biddings are

- open bidding, this is the main type of bidding that is held in China, all qualified participants are allowed to take part;

- selective bidding, bidding with a limited number of participants (several qualified participants), predetermined suppliers;

- competitive negotiations are used in case of failure of the tender procedure, for example, when the standards are technically complex, or when there is a need for an urgent tender;

- purchases from a single supplier; this type of purchase is used when there is only one possible supplier, if there is an additional purchase with a low cost below $10 \%$ of the original contract), if the purchase is made to prevent an emergency.

An official website has been created to publish information about public procurement in China www.ccgp.gov.cn. The site provides information for potential suppliers about ongoing purchases of goods/workslservices, publishes details of completed transactions, including the prices offered by various suppliers for specific items of the past purchase [9].

To understand the specifics of logistics institutions in the international procurement, let's look at the differences in public procurement procedures in the Russian Federation and China (Table I).

As a result of a comparative analysis of regulatory documents and procedures for public procurement in the Russian Federation and the PRC, discrepancies were revealed, since 44-FZ of the Russian Federation is a direct law that describes all possible situations and prevents commercial risks, while the GPL law of the PRC is a framework law that describes only the basic principles of public procurement, other subtleties of public procurement are regulated by other secondary legislations. Also there are differences in the timing of the conclusion of state contracts on the results of the procurement procedure (terms of the announcement between the procurement and the purchase deadline, waiver of bidding, the period of the contract, provide reports on results of procurement). A significant feature of the Chinese procurement is to provide the customer with the opportunity to inspect the proposed location of the project in advance, and submit copies of the concluded state contract to the Department of supervision of the public procurement process. This indicates a more rigid control function of the Chinese procurement. The policy of digital transformation of public procurement in China is being implemented likewise. For example, machine learning capabilities transform the procurement process while maintaining government regulation [10]. So, machine learning technologies not only help choosing the right type of competition, but also allow determining which suppliers should be invited to participate in the bidding, avoiding the risks of working with unscrupulous partners. Based on the big data analytics tools, customers can study the market situation and be guided by the cost-effective price when entering into a government contract. All this, including "the use of advanced information technologies (electronic trading systems, online stores and electronic trading platforms, mobile applications, B2B marketplace, etc.) serves to implement technical methods to combat abuse, inefficiency and corruption in the field of procurement" [11]. The Chinese procurement demonstrates the strengthening of the state's regulatory functions in the digital economy, which is reflected in the institutional support of procurement procedures. Based on the fact that institutional changes determine how societies evolve over time, we will try to find a key to understanding the historical changes caused by the digital transformation of public procurement. To do this, we need to clarify a number of fundamental theoretical provisions of the institutional support of the logistics system of public procurement.

Let's pay attention to the fact that logistics institutions in the procurement are a subsystem of the national economy that implements the regulatory, supporting and ensuring functions and interactions of business entities within the framework of the public procurement system. Based on the fact that "real economic activity is carried out not through the direct involvement of certain institutions, but through the management of subjects of relations through the definition of norms and rules of their behavior that make up a certain structural totality", we turn to the term institutional agreement", which characterizes "the result of effective functioning of infrastructure institutions aimed at developing the system, reducing transaction costs, minimizing market failures and interactions of business entities with institutional infrastructure" [12, p.16].

According to D. North, institutions are "the rules of the game" in society, or, to put it more formally, man-made restrictive frameworks that organize relationships between people. Therefore, they set "the structure of motivational motives of human interaction-whether in politics, social sphere or economy" [12, p. 17].

"Institutions reduce uncertainty by structuring everyday life" [12, p. 18]. And this thesis is important to take into account when conducting digital transformations in the procurement, since the introduction of digital innovations in an unfavorable institutional environment faces a number of constraints and obstacles, which leads to negative consequences [13, 14]. This problem fully applies to the logistics of public procurement. 
TABLE I. COMPARATIVE ASSESSMENT OF REGULATORY DOCUMENTS AND Public PROCUREMENT PROCEDURES IN RuSSiA AND CHINA [15]

\begin{tabular}{|c|c|c|}
\hline $\begin{array}{c}\text { Criterion } \\
\text { (document) }\end{array}$ & $\begin{array}{l}\text { The Federal Law of April } \\
5,2013 \text { N } 44-F Z \text { "On the } \\
\text { contract system in the } \\
\text { field of procurement of } \\
\text { goods, works, services to } \\
\text { meet state and municipal } \\
\text { needs" }\end{array}$ & $\begin{array}{c}\text { The Government } \\
\text { Procurement Law of the } \\
\text { People's Republic of China } \\
\text { (Order of the President } \\
\text { No.68). }\end{array}$ \\
\hline $\begin{array}{l}\text { Application } \\
\text { area }\end{array}$ & $\begin{array}{l}\text { Regulates the relations } \\
\text { aimed at ensuring state and } \\
\text { municipal needs in order to } \\
\text { increase the efficiency and } \\
\text { effectiveness of the goods } \\
\text { procurement, works, } \\
\text { services, ensure publicity } \\
\text { and transparency in the } \\
\text { implementation of such } \\
\text { purchases, and prevent } \\
\text { corruption and other } \\
\text { abusive activities. }\end{array}$ & $\begin{array}{l}\text { Regulates the activities of } \\
\text { public procurement, } \\
\text { increasing the efficiency of } \\
\text { the public procurement } \\
\text { funds use, protecting the } \\
\text { interests of the state and the } \\
\text { public, protecting the } \\
\text { legitimate rights and } \\
\text { interests of the parties to } \\
\text { public procurement, and } \\
\text { promoting the integrity of } \\
\text { the government. }\end{array}$ \\
\hline $\begin{array}{l}\text { Regulation } \\
\text { area }\end{array}$ & $\begin{array}{l}\text { Planning the procurement } \\
\text { of works, goods, services; } \\
\text { determination of suppliers } \\
\text { (contractors, performers); } \\
\text { conclusion of contracts; } \\
\text { specifics of contract } \\
\text { execution; monitoring of } \\
\text { goods, works, services; } \\
\text { audit in the field of } \\
\text { procurement of goods, } \\
\text { works, services; control } \\
\text { over compliance with } \\
\text { legislation. }\end{array}$ & $\begin{array}{l}\text { Public procurement } \\
\text { methods; parties to public } \\
\text { procurement; specifics of } \\
\text { concluding a public } \\
\text { procurement contract; the } \\
\text { procedure for sending } \\
\text { inquiries and complaints; } \\
\text { supervision and inspection } \\
\text { of public procurement } \\
\text { activities; legal obligations } \\
\text { of the parties }\end{array}$ \\
\hline $\begin{array}{l}\text { Law } \\
\text { characteriza } \\
\text { tion }\end{array}$ & Directly applicable & Framework \\
\hline $\begin{array}{l}\text { Ways of } \\
\text { supplier } \\
\text { determining }\end{array}$ & $\begin{array}{l}\text { Competitive and single } \\
\text { supplier procurement }\end{array}$ & $\begin{array}{l}\text { Competitive and single } \\
\text { supplier procurement }\end{array}$ \\
\hline $\begin{array}{l}\text { Pre- } \\
\text { qualificatio } \\
\text { n selection }\end{array}$ & Provided & Provided \\
\hline $\begin{array}{l}\text { Criteria for } \\
\text { evaluating } \\
\text { and } \\
\text { comparing } \\
\text { applications } \\
\text { for } \\
\text { participatio } \\
\mathrm{n} \text { in the } \\
\text { tender }\end{array}$ & $\begin{array}{l}\text { Contract price; expenses } \\
\text { for the operation and repair } \\
\text { of goods, the use of the } \\
\text { results of work; quality, } \\
\text { functional and } \\
\text { environmental } \\
\text { characteristics of the } \\
\text { procurement object; } \\
\text { qualification of } \\
\text { procurement participants }\end{array}$ & $\begin{array}{l}\text { Comprehensive criteria for a } \\
\text { fair price, compliance with } \\
\text { actual requirements and the } \\
\text { verification of the } \\
\text { procurement object price }\end{array}$ \\
\hline $\begin{array}{l}\text { The period } \\
\text { between the } \\
\text { announcem } \\
\text { ent of the } \\
\text { purchase } \\
\text { and the end } \\
\text { of the bids } \\
\text { acceptance }\end{array}$ & $\begin{array}{l}\text { Tender - at least } 20 \text { days. } \\
\text { Bidding - at least } 7 \text { days (if } \\
\text { the guaranteed maximal } \\
\text { contract price is less than } 3 \\
\text { million rubles), at least } 15 \\
\text { days (if the guaranteed } \\
\text { maximal contract price is } \\
\text { more than } 3 \text { million rubles) }\end{array}$ & At least 20 days \\
\hline $\begin{array}{l}\text { Waiver of } \\
\text { bidding }\end{array}$ & $\begin{array}{l}\text { Not later than } 5 \text { days } \\
\text { before the deadline for } \\
\text { applications }\end{array}$ & Not provided \\
\hline $\begin{array}{l}\text { Interactions } \\
\text { between the } \\
\text { customer } \\
\text { and the } \\
\text { supplier } \\
\text { before } \\
\text { determining } \\
\text { the winner }\end{array}$ & Not provided & $\begin{array}{l}\text { Inspection and examination } \\
\text { of the project site are } \\
\text { possible }\end{array}$ \\
\hline $\begin{array}{l}\text { The } \\
\text { condition } \\
\text { when the }\end{array}$ & $\begin{array}{l}\text { In case if at any stage of } \\
\text { the procurement, either one } \\
\text { application remains or }\end{array}$ & $\begin{array}{l}\text { Submission of less than } 3 \\
\text { applications from potential } \\
\text { suppliers }\end{array}$ \\
\hline
\end{tabular}

\begin{tabular}{|c|c|c|}
\hline $\begin{array}{l}\text { Criterion } \\
\text { (document) }\end{array}$ & $\begin{array}{l}\text { The Federal Law of April } \\
5,2013 \text { N 44-FZ "On the } \\
\text { contract system in the } \\
\text { field of procurement of } \\
\text { goods, works, services to } \\
\text { meet state and municipal } \\
\text { needs" }\end{array}$ & $\begin{array}{c}\text { The Government } \\
\text { Procurement Law of the } \\
\text { People's Republic of China } \\
\text { (Order of the President } \\
\text { No.68). }\end{array}$ \\
\hline $\begin{array}{l}\text { procedure is } \\
\text { declared } \\
\text { invalid }\end{array}$ & there is none & \\
\hline $\begin{array}{l}\text { Evaluation } \\
\text { of } \\
\text { applications } \\
\text { received } \\
\end{array}$ & $\begin{array}{l}\text { Commission organized by } \\
\text { the customer }\end{array}$ & Evaluation Committee \\
\hline $\begin{array}{l}\text { Right to ask } \\
\text { for any } \\
\text { clarification } \\
\text { after } \\
\text { bidding }\end{array}$ & $\begin{array}{l}\text { Five days before the } \\
\text { deadline for applications } \\
\text { submission }\end{array}$ & $\begin{array}{l}\text { On request of application, } \\
\text { without changing the main } \\
\text { provisions of the application } \\
\text { and price }\end{array}$ \\
\hline $\begin{array}{l}\text { Contract } \\
\text { period }\end{array}$ & $\begin{array}{l}\text { Competition not earlier } \\
\text { than } 10 \text { and not later than } \\
20 \text { days. Bidding - within } 5 \\
\text { days. Request for } \\
\text { proposals and request for } \\
\text { quotations - no earlier than } \\
7 \text { days and no later than } 20 \\
\text { days. }\end{array}$ & $\begin{array}{l}\text { Within } 30 \text { days from the date } \\
\text { of sending the notice of } \\
\text { winning the purchase. }\end{array}$ \\
\hline $\begin{array}{l}\text { Reports } \\
\text { provision on } \\
\text { the results } \\
\text { of } \\
\text { conducted } \\
\text { biddings }\end{array}$ & Not provided & $\begin{array}{l}\text { Within } 7 \text { days from the date } \\
\text { of conclusion of the contract, } \\
\text { the procuring entity submits } \\
\text { a copy of the contract to the } \\
\text { department }\end{array}$ \\
\hline
\end{tabular}

Our theoretical analysis of the transformation of logistics institutions in the procurement demonstrated that it is important to form institutions that promote resource conservation, support innovation, and the development of small and medium-sized businesses. In this regard, it is useful to refer to the experience of the Chinese procurement, when small businesses and national innovations are supported at the legislative level.

In this regard, logistics institutions create the legal and organizational foundation for economic relations between participants in the public procurement system. This may be a certain form of organization, regulation and regulation of public procurement logistics; a form of interaction between participants in the contract system; a group of interrelated homogeneous economic or social relations; specific methods of organizing and managing economic flows; elements of the social structure of society. The analysis showed that the difficulties faced by the current public procurement system are largely due to institutional instability. In turn, institutional uncertainty and instability in the public procurement market generates high logistics costs, additional transaction costs, and abuse.

The digital transformation of the economy makes its own adjustments to the functioning of existing logistics institutions in the procurement. This is manifested in the optimization time for the complete cycle of procurement, which positively affects the work of the parties and rationalize their transaction: the period is reduced and the transparency of the procurement cycle is increased; the procedure of pre-qualification and evaluation of suppliers is optimized; transparency and clarity of the procurement cycle, as well their monitoring and auditing processes are increased; geographical access and participation in tenders are expanded, etc. 


\section{CONCLUSION}

Institutional support of public procurement logistics encourages the creation of institutions that implement management and regulation of the activities of procurement participants in the modern hybrid (virtual and real) world; the use of innovative ways of their interaction. This is possible on the basis of taking into account the positive international and domestic experience implemented in the form of a digital logistics system of public procurement.

The macrologistic system of public procurement includes the following elements-links: structures authorized to control and monitor logistics flows; links representing state customers, suppliers and potential consumers; structures that Finance and insure public procurement; electronic trading platforms, marketplaces, consulting companies; links that provide information support for the public procurement cycle.

Such a system is an information and communication digital platform that integrates the logistics flow of participants in procurement procedures (link elements).

The logistics system of public procurement belongs to the group of socio-economic systems; its goal is to increase the efficiency of public procurement based on the harmonization of logistics flow management [16]. The procurement cycle management in this system is based on the institutional and organizational alliance of the state and private business, on the symbiosis of the principles of procurement and logistics management. This makes it possible to ensure openness, transparency, competitiveness and efficiency of public procurement; a combination of market and planned methods for regulating the full procurement cycle.

\section{Acknowledgments}

The reported study was funded by RFBR, project number 20-010-00141 120". "Formation of the institutional framework of the region's infrastructure in digital economy.

\section{References}

[1] I.D. Afanasenko, and V.V. Borisova, Digital Logistics: A Textbook for Universities [Cifrovaya logistika: Uchebnik dlya vuzov], SPb.: Piter, 2018. [In Russ.].

[2] I.D. Afanasenko, and V.V. Borisova, Institutional foundations of logistics systems [Institucional'nye osnovy logisticheskih sistem] /Logistika v sisteme sovokupnogo znaniya, SPb.: SPbGEU, 2013.[In Russ.].

[3] I.D. Afanasenko, Russia in a changing world [Rossiya v izmenyayushchemsya mire], SPb.: SPbGEU, 2019. [In Russ.].

[4] V.V. Borisova, and P.A. Kudryashova, "Virtual logistics operators: foreign experience and Russian practice" [Virtual'nye logisticheskie operatory: zarubezhnyj opyt i rossijskaya praktika], Izvestiya SanktPeterburgskogo gosudarstvennogo ekonomicheskogo universiteta, 2019, vol. 2(116), pp. 83-89. [In Russ.].

[5] J. Xuedong, "Digital innovations in public procurement logistics" [Cifrovye innovacii $\mathrm{v}$ logistike gosudarstvennyh zakupok], in Proceedings of MNPK on Rostov n/D, 2019, pp. 135-139. [In Russ.].

[6] N.S. Pechenko, V.V. Borisova, and A.V. Molonova, "Digital transformation of Eurasian Economic Union's (EAEU) logistics system", Atlantis Highlights in Computer Sciences, 2019, vol. 1, pp. 20-24.

[7] V.V. Borisova., and S. Czya, "State procurement in China and unit of logigstics lows" [Gosudarstvennyj prok'yurement v Kitae i edinstvo logisticheskih potokov], Vestnik Rostovskogo gosudarstvennogo ekonomicheskogo universiteta, 2020, vol. 1(61) [Appear]. [In Russ.]

[8] P. Wang, "China's Evolving Legal Framework on Public Procurement", Public Procurement Law Review, 2004, vol. 6, pp. 285-318.

[9] V.V. Borisova, T.S. Tasueva, and B.K. Rakhimova, "Digital and Innovative Aspects State Support for Digital Logistics", in Proceedings of 21st Century from the Positions of Modern Science on Intellectual, Digital and Innovative Aspects State Support for Digital Logistics, 2019, pp. 631-638.

[10] L.I. Pogorelova, and N.A. Babkina, "Comparative analysis of the features of the functioning of public procurement in Russia and the PRC" [Sravnitel'nyj analiz osobennostej funkcionirovaniya gosudarstvennyh zakupok v Rossii i KNR], in Proceedings of MNPK on Rossiya i Kitaj: vektor razvitiya, 2017, pp. 201-203. [In Russ.]

[11] Procurement with intelligence: experts called "smart" services [Zakupki s intellektom: eksperty nazvali «umnye» servisy]. (In Russ.). Retrieved from https://torg94.ru/articles/zakupki-s-intellektom-eksperty-nazvaliumnyeservisy-2017-06-09

[12] D. Nort, Institutions, institutional change and the functioning of the economy [Instituty, institucional'nye izmeneniya i funkcionirovanie ekonomiki], Moscow: Fond ekonomicheskoj knigi «Nachala», 1997. [In Russ.].

[13] E.G. Popkova, I.V. Lysak, I.N. Titarenko, V. Golikov, and I.A. Mordvintsev Philosophy of Overcoming "Institutional Traps" and "Black Holes" Within the Global Crisis Management, Chapter in the book: Overcoming Uncertainty of Institutional Environment as a Tool of Global Crisis Management, in: E.G. Popkova (Ed.), New York City: Springer International Publishing AG, 2017.

[14] N.S. Pechenko, "Formation and development of the digital space of the Eurasian Economic Union" [Formirovanie i razvitie cifrovogo prostranstva Evrazijskogo ekonomicheskogo soyuza], in Proceedings of XIV mezhdunarodnoj nauchno-prakticheskoj konferencii Sovremennyj menedzhment: problemy i perspektivy, 2019, pp. 782-784. [In Russ.]

[15] J. Xuedong, "Public procurement of China as an object of logistics in China" [Gosudarstvennye zakupki Kitaya kak ob"ekt logistizacii Kitaya], Izvestiya Sankt-Peterburgskogo gosudarstvennogo ekonomicheskogo universiteta, 2020, vol. 4. [In Russ].

[16] V. Plotnikov, G.V. Fedotova, E.G. Popkova, and A.A. Kastyurina, "Harmonization of Strategic Planning Indicators of Territories' Socioeconomic Growth", Regional and Sectoral Economic Studies, 2015, vol. 15(2), pp. 105-114. Retrieved from http://www.springer.com/gp/book/9783319606958\#otherversion=97833 19606965 